\title{
Risk Management of Commercial Banks in Kosovo
}

Submitted 29/08/19, $1^{\text {st }}$ revision 26/09/19, $2^{\text {nd }}$ revision 16/10/19, Accepted 05/11/2019

\author{
Muhamet Aliu ${ }^{1}$, Arbana Sahiti ${ }^{2}$, Albina Kalimashi ${ }^{3}$
}

\begin{abstract}
:
Purpose: This research elaborated on the management of the activity of banks operating in Kosovo.

Design/Methodology/Approach: The study provided for the secondary service by reporting goals for the four largest banks in Kosovo.

Findings: Problems of commercial banks of Kosovo in managing risks for establishing concepts for managing the activity, defects of the activity management system and backwardness of the research and method of managing the activity.

Practical Implications: With the continued development of the financial sector, commercial banks in Kosovo have formed a series of strict risk management systems, while the risk management of commercial banks in Kosovo is still in its infancy. As Kosovo's financial industry is opening up to the outside world, Kosovo's banking industry faces increasingly fierce competition and the risks are also more complex. In this case, understanding the level of risk management of commercial banks in Kosovo and improving the level of risk management is a necessary topic.
\end{abstract}

Originality/Value: The results of the study realize a series of meaningful suggestions are put forward and help to improve the risk management level and control the risks effectively

Keywords: Banks, Risk management, liquidity, ROE, NPL.

JEL Codes: C32, C33, G21, H2.

Article Type: Research study.

\footnotetext{
${ }^{1}$ University of Pristina, Associate Professor, PhD, Faculty of Economic, Department of Bank, Finance and Accounting, muhamet.aliua@uni-pr.edu ${ }^{2}$ University of Pristina, PhD candidate, Faculty of Economics, Department of Bank, Finance and Accounting, corresponding author arbana.sahiti@uni-pr.edu ${ }^{3}$ University of Pristina, MSC, Faculty of Economics, Department of Bank, Finance and Accounting.
} 


\section{Introduction}

As the main part of a nation's financial sector, commercial banks and their risk problems have been a research that focuses on government and bank itself. Since the birth of commercial banks, earnings and risk are always accompanied by commercial banks. The goal of commercial banks is profit, but the risk is the costs that banks in pursuit of benefits. Commercial banks will have to bear the risk in order to get high returns. In contrast, if banks do not want to take risks, it can only get average earnings. Therefore, in the development of commercial banks, how to prevent and control risks in the process of the pursuit of profit is an important problem that makes bank managers take seriously and spend energy and time. International commercial banks experienced such a process below for the risk management and prevention.

In the 1980s, savings and loan institutions have emerged a large number of collapses because of credit risk. In this case, the banks started to generally pay attention to the prevention and management of credit risk. The Basel Agreement has played a huge role to protect the security of the commercial banks. After 1990s, with the rapid growth of financial derivatives and trading, the market risk is emphasized. And most of the commercial banks in the world put their focus on expanding the business and neglect the risk control and supervision. As a result, in the mid of 1990s, there was a worldwide crisis of banks and financial institution, such as the 1995 British Barings bank collapse and the Daiwa Bank scandal in 1996. In this situation, some of the major international banks began trying to study and set up their own internal risk measurement method to make up the deficiency of the Basel Agreement.

However, in the late 1990s, the Asian financial crisis led to the world financial turmoil again. In this crisis, many famous worldwide big banks suffered losses. In particular, LCAM, the US Company that consists of the Wall Street financial elites, former treasury officials and Nobel laureate in economics is also close to bankruptcy. The risk of commercial banks will exist forever. At the end of 2008, the subprime crisis caused the volatility and fall of US stock market, and it led to the global financial crisis.

It can be seen in this crisis that the banking completion is intensifying with the development of financial globalisation. In order to win in competition, banks are increasing their financial innovation. And for the purpose of pursuit of greater benefits, some of the financial institutions of developed countries tend to create financial products that could avoid regulation. This approach ignores the importance of comprehensive risk management. If the economic situation has a large negative changes, cumulative risk will be exposed and lead to a crisis.

This series of international bank crisis events caused by risk proved the importance of good risk management for the banking industry development. Although some of the banking industry of developed countries such as the US and UK have been very 
attention to risk management and prevention and it has formed a set of more scientific and standardised system of risk management, the risk management and control of banking industry is still a big problem.

Risk management is an important part of enterprise management. Effective and sound risk management could promote the stability of the banks and industry. It can provide more confidence when the investors and counterparty invest financial plan they want. Banks could use a powerful risk management control system from internal, due to the strong business and economic incentives. If there is no such control, banks will face to risk. The importance of risk management is to prevent and control accidental loss through recent conditions.

Oldfield \& Santomero, (1997) studied the risk management of financial organisations and put forward the four steps for positive risk management. These four steps are respectively set up standards of financial reporting, the position limits and rules, create guidelines and strategic investment by self, as well as the incentive contracts and compensation. Bace, (2016) shows a relationship between the loans-tocore deposit ratios and liquidity risk. After continuing to study for a period of time, he pointed out that a change of banks' assets and liabilities management. At the same time, he also believes that there is a positive relationship between the loan-to-core deposits and market risk after 1994. In the market competition, risk depends on the size and structure of the risk management in banks (Niinimäki, 2004) Although banks could avoid extreme risk-taking, banks are inclined to take risks in certain conditions. Otherwise, if the banks in the competition for deposits, it will increase the risk of bank by using the deposit insurance system. In this situation, it will force banks to assume extreme risks due to the high savings rate.

In some specific countries, after studying the relationship between efficiency and risks in the large banks of USA, Fan \& Shaffer, (2004) found that the profit efficiency is relatively sensitive to bankruptcy risk and credit risk, while it is not sensitive to loan product portfolio and liquidity risk. Khambata \& Bagdi, (2003) studied the credit risk that off-balance sheet of the top 20 banks in Japan. The result shows that financial derivatives are largely used in four banks. And it displayed that the loan commitment is the main source of credit risk in the traditional off-balance sheet structure. Hassan Al-Tamimi \& Mohammed Al-Mazrooei, (2007), main methods used in the risk management of UAE commercial banks are to establish a standard, credit analysis, risk evaluation, credit scores and guarantee. It also highlighted the use of the most advanced risk management techniques in the study, and suggested adopting conservative lending policies. The results of this study found that the banking regulation policy issues which are the role of banking competition, the advantages of bank managers from different regions, the use of early warning indicators that are bank-level variables and ownership in determining credit risk. In Korea, Hahm, (2004) has an empirical research about the interest rate risk and exchange rate risk of banking institutions before crisis. The research shows that commercial banks in Korea are obviously appeared the interest rate risk and 
exchange rate risk, and subsequent profitability of banks affected by the economic crisis. The research results also show that the situation of Korea highlights the importance of risk management and upgrading financial regulation. And it is the precondition of financial liberalization.

However, in Kosovo, there is only a small number of empirical studies, the empirical study of Kosovo scholars also stays on the introduction to a theoretical level. And there is no actual and effective empirical analysis of risk management.

\section{Methodology}

Sample method could be divided into two categories, probability and non-probability respectively. These two types of sampling are also called random sampling and nonrandom sampling. Probability sampling is refers to each unit of the population has the equal chance to be selected while the non-probability sampling means that the opportunity of each unit to be selected is not equal (Sekaran \& Bougie, 2013). For this research, according to the research objective, it will use the non-probability sampling. Based on the non-probability sampling, purposive sampling is the best choice for this research. Purposive sampling is to choose a more representative sample and can lead to more accurate results than other probability sampling.

In this research, mainly commercial bank risk management in Kosovo is discussed. According to the Central Bank of Kosovo (CBK) survey in 2019 there are 11 banks In order to better implement the research objective, according to the basic situation of commercial banks, the "big four" banks will be selected in all commercial banks including Procredit Bank (PCB) Raiffesen Bank (RBKO), TEB Bank (TEB), NLB Bank (NLB)

"Big Four" commercial banks have representative. Compared with the commercial banks in the capitalist country, commercial banks in Kosovo are completely controlled by the state although these banks are joint-stock system. "Big four" commercial banks, as the leader of commercial banks in Kosovo, could represent other Kosovo commercial banks' risk management, because other commercial banks are all follow the steps of "Big four" to a certain extent. And the four commercial banks occupied $80 \%$ of resources of the Kosovo banking industry. On the other hand, due to the big gap between commercial banks and its inequality, random sampling cannot be selected in this research. Choosing non-random sampling could ensure the balance of the samples and be able to fully reflect the research purpose.

In this research, secondary data have two main official sources. The first source is the annual reports from the "Big four" commercial banks, mainly including its financial statement and risk management reports. And other reports related to the risk analysis and risk management issued by the main commercial banks. This information is based on data collected from the perspective of internal of commercial banks. The second source is risk management reports that released by Central Bank 
of Kosovo. From the point of the data selection, this research mainly uses data and information in recent five years (2014-2018). There are two main reasons. Firstly, data has timeliness. To understand the latest status of the banking industry, it must use the latest data to measure. Data in nearly five years could ensure the timeliness and also can understand the trend of the development of the banking sector.

\section{Findings and Discussions}

There are two main analytical methods in this study. One is baseline ratio analysis and the other is sensitivity analysis. These two methods have been used to measure risk management in different commercial banks. Furthermore, clear and effective use of Excel can help analyze and compare commercial banks' risk management in Kosovo.

\subsection{Capital Adequacy Ratio}

Capital adequacy ratio (CAR) is the ratio of bank capital to risk-weighted assets. It represents the last debt paying ability of bank debt. CAR is an important index that measure robustness of banks and the ability of resisting risk. It is also the most main regulation indicators of international banking. CAR emphasized the supervision and protection of banks. Basel Agreement identified $8 \%$ as the CAR requirement in 1988. And Kosovo also has established this risk control indicators from 2001 (Table 1).

Table 1. The Capital Adequacy Radios of the Big Four Commercial Banks (\%)

\begin{tabular}{|c|c|c|c|c|c|}
\hline \multirow{2}{*}{ Banks } & \multicolumn{5}{|c|}{ Years } \\
\cline { 2 - 6 } & 2014 & 2015 & 2016 & 2017 & 2018 \\
\hline PCB & 12.3 & 12.27 & 13.17 & 13.66 & 13.12 \\
\hline RBKO & 10.07 & 11.59 & 11.94 & 12.61 & 11.86 \\
\hline TEB & 11.14 & 2.58 & 12.97 & 13.63 & 12.46 \\
\hline
\end{tabular}

Source: Authors'calculations.

The data in Table 1 shown that the CARs of four commercial banks are all over $8 \%$ and more than the international standard from 2014 to 2018. The higher the CAR of commercial banks, it means the greater the ability to bear the risk of default. However, in 2018, the CAR of four commercial banks dropped by at least $1 \%$, although it still above the regulatory standards. This is due to the central bank redefinition the calculation method of bank capital. Under the influence, the CAR of commercial banks generally decline.

\subsection{Non-Performing Loans}

In the assets business of commercial banks in Kosovo, the dominant is the loan business. And credit risk is the major risk of the loan business. Therefore, the main 
risk in commercial banks is showed as credit risk. Here will be analyzing the current situation of credit risk on several aspects of the big four state-owned commercial banks. Loans in commercial banks can be divided into five parts (including Pass, Special Mention, Substandard, Doubtful and Loss), namely five-tier classification. Among them, the substandard, doubtful and loss is referred to non-performing loans (NPLs). Credit risk in commercial banks of Kosovo is mainly characterized by accumulation of huge NPLs to the bank. A common view is that the high speed expansion in the loan process of commercial banks, the non-performing loans is increasing.

Table 2 and Figure 1 shows the amount and the percentage of NPLs of the four commercial banks. From 2014 to 2018, NPLs of the big four state-owned commercial banks generally showed a fluctuant rising tendency, although the NPL ratios are declining slightly. By the end of 2018, the total amount of NPLs of four commercial banks is increasing to 301489 million and the NPL ratio is $1.035 \%$.

Table 2. Non-performing Loans of Big Four Commercial Banks (RMB: Million)

\begin{tabular}{|r|r|l|r|r|r|r|r|r|r|r|}
\hline Banks & \multicolumn{2}{|c|}{ PCB } & \multicolumn{2}{c|}{ RBKO } & \multicolumn{2}{c|}{ TEB } & \multicolumn{2}{c|}{ NLB } & & \\
\hline Years & Amount & $\%$ & Amount & $\%$ & Amount & $\%$ & Amount & $\%$ & AVG & $\%$ \\
\hline $\mathbf{2 0 1 4}$ & 88,467 & 1.54 & 120,241 & 2.91 & 74,718 & 1.52 & 72,156 & 1.5 & 355,582 & 1.8675 \\
\hline $\mathbf{2 0 1 5}$ & 73,241 & 1.08 & 100,405 & 2.03 & 62,470 & 1.1 & 64,723 & 1.14 & 300,839 & 1.3375 \\
\hline $\mathbf{2 0 1 6}$ & 73,011 & 0.94 & 87,358 & 1.55 & 63,247 & 1 & 70,918 & 1.09 & 294,534 & 1.145 \\
\hline $\mathbf{2 0 1 7}$ & 74,575 & 0.85 & 85,848 & 1.33 & 66,448 & 0.96 & 74,618 & 0.99 & 301,489 & 1.0325 \\
\hline
\end{tabular}

Source: Authors 'calculations.

Figure 1. NPLs of Big Four Commercial Banks

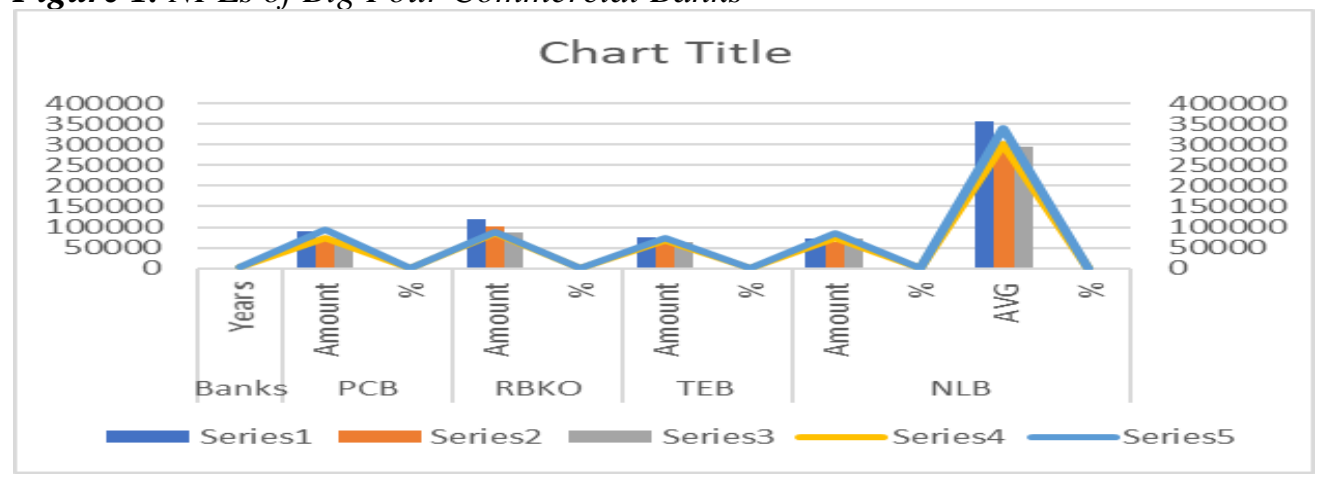

Specifically, although only the NPL ratio of RBKO is declined year by year from 2014 while the other three banks' (PCB TEB and NLB) ratio are increased in 20172018, the NPL ratio of RBKO is still the highest in the four banks and reach to $1.33 \%$. Moreover, amounts of NPLs of these four banks are showed a gradually rising trend since 2015. There in, PCB and TEB showed a "two-liter" of the NPLs and NPL ratios. The above information means that the deterioration of credit risk in 
a certain extent compared with previous years, despite the current data is in good condition according to the credit risk of commercial banks.

\subsection{Types and Distribution of Credit Risk}

In addition to the overall NPLs and NPL ratios, commercial banks also reveal a more detailed data about industrial and regional distribution of NPLs. In this section, it is mainly analysis the assets quality in different industries of the big four commercial banks. Loans in banks can be divided into two categories, the corporate loans and personal loans. It exist certain difference of different types of loans. According to Table 3, the NPL ratio of company loans in commercial banks is significantly higher than the personal loans. From 2014 to 2018, the average NPL ratio of company loans to these four commercial banks is $1.561 \%$ but the personal loans are $0.669 \%$. It is important to note that there is a large difference in asset quality between the company loans and personal loans, such as NLB, the NPL ratio of company loans is 3 more than times of personal loans.

Table 3. Types and Distribution of Credit Risk

Distribution of Loans d NLP by Bussiness Line (\%)

\begin{tabular}{|c|c|c|c|c|c|c|}
\hline Year & & PCB & RBKO & TEB & NLB & AVG \% \\
\hline \multirow{2}{*}{2014} & $\begin{array}{l}\text { Company } \\
\text { loans }\end{array}$ & 1.94 & 3.66 & 1.75 & 1.71 & 2.256 \\
\hline & $\begin{array}{l}\text { Personal } \\
\text { loans }\end{array}$ & 0.83 & 1.4 & 0.89 & 0.66 & 0.945 \\
\hline \multirow{2}{*}{2015} & $\begin{array}{l}\text { Company } \\
\text { loans }\end{array}$ & 1.31 & 2.48 & 1.29 & 1.14 & 1.555 \\
\hline & $\begin{array}{l}\text { Personal } \\
\text { loans }\end{array}$ & 0.59 & 0.96 & 0.64 & 0.43 & 0.655 \\
\hline \multirow{2}{*}{2016} & $\begin{array}{l}\text { Company } \\
\text { loans }\end{array}$ & 1.15 & 1.9 & 1.15 & 1.43 & 1.408 \\
\hline & $\begin{array}{l}\text { Personal } \\
\text { loans }\end{array}$ & 0.54 & 0.78 & 0.56 & 0.31 & 0.548 \\
\hline \multirow{2}{*}{2017} & $\begin{array}{l}\text { Company } \\
\text { loans }\end{array}$ & 0.96 & 1.64 & 1.2 & 1.36 & 1.29 \\
\hline & $\begin{array}{l}\text { Personal } \\
\text { loans }\end{array}$ & 0.59 & 0.76 & 0.62 & 0.29 & 0.565 \\
\hline \multirow{2}{*}{2018} & $\begin{array}{l}\text { Company } \\
\text { loans }\end{array}$ & 1.04 & 1.51 & 1.18 & 1.42 & 1.288 \\
\hline & $\begin{array}{l}\text { Personal } \\
\text { loans }\end{array}$ & 0.75 & 0.74 & 0.72 & 0.32 & 0.633 \\
\hline
\end{tabular}

Source: Authors' calculations.

Further, for company loans, different direction of loan investment shows different characteristics in the credit risk. It can be seen from Table 3, the top three industries 
of NPL ratios in these four banks in 2018 are wholesale and retail industry, IT industry and manufacturing industry, and the average NPL ratios are $3.063 \%$, $1.667 \%$ and $2.388 \%$. At present, manufacturing and retail (which industries have longer periodic) is usually the main industry that direction of loan investment of banks and occupies a large share. This means that these major industries are faced with a relatively high credit risk. Once the economy slows or meets bigger downward pressure, it will seriously affect the solvency and caused the credit risk.

\subsection{Provision Coverage (Allowance to NPLs)}

Provision coverage refers to the use of banks loans to the possibility of bad debt reserve ratio. It mainly reflects the offset ability of loan losses and the present capacity of loan risk of commercial banks. The higher the ratio shows the better the ability to resist risk, but the discretion of this rate should be suited to the degree of risk. Table 4 and Figure 2 is the basic condition of the provision coverage in the four commercial banks in Kosovo from 2014 to 2019.

Table 4. The Allowance to NPLs of Big Four Commercial Banks

\begin{tabular}{|l|r|r|r|r|r|}
\hline \multicolumn{7}{|c|}{ Years } \\
\hline Banks & $\mathbf{2 0 1 4}$ & $\mathbf{2 0 1 5}$ & $\mathbf{2 0 1 6}$ & $\mathbf{2 0 1 7}$ & $\mathbf{2 0 1 8}$ \\
\hline PCB & 164.41 & 228.2 & 266.92 & 295.92 & 257.19 \\
\hline TEBO & 105.37 & 168.05 & 263.1 & 326.14 & 367.04 \\
\hline NLB & 151.17 & 196.67 & 220.75 & 236.3 & 229.35 \\
\hline
\end{tabular}

Source: Authors 'calculations.

Figure 2. AVG\% Of Allowance to NPL

AVG \% OF ALLOWANCE TO NPLS

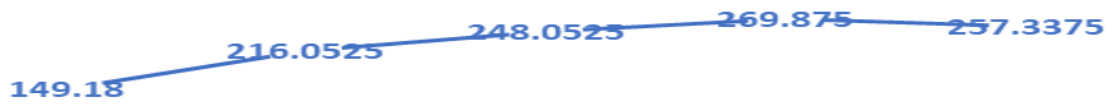

2014

2015

2016

2017

2018

The allowance to NPLs keeps at a high level of commercial banks in Kosovo. In 2018, the average allowance to NPLs of four commercial banks reaches to $257.338 \%$, and much higher than the regulatory standards (the standard set by CBK is $150 \%$ ). This illustrates the loss provision is prepared to banks and it could cover the current credit risk. Look at the trend, the average percentage of allowance to NPLs presents a decrease. It falls to $257 \%$ in 2018 from $269 \%$ at the end of 2017 , although it still keeps at a higher level and more than the regulatory standards. One factor of decline is related to the increasing of NPL ratios of commercial banks. On the other hand, in the large current operating pressure, commercial banks are not willing to make more reserves in order to avoid the impact on current performance. 


\subsection{Liquidity Risk}

Liquidity of bank assets is mainly refers to the difficulty of assets realization. In general, the more liquid assets tend to show a lower risk. There are two characteristics that measure liquidity, static characteristic and dynamic characteristic. The static characteristics focused on the project in the balance sheet and financial ratios between various projects. And the dynamic characteristics focus on the potential liquidity needs of banks and the ability to meet these needs, which involve the off-balance sheet business.

\section{Liquidity Ratio:}

Liquidity ratio is the ratio of current assets and current liabilities of commercial banks. It reflects the solvency when banks under pressure to pay. The higher the current ratio shows that the higher the liquidity of the bank storage. However, in general, the liquidity ratio is smaller if the size of the bank is bigger; because of the large commercial banks generally do not need to store too much liquidity. Table 5 describes the liquidity ratios of the big four commercial banks from 2014 to 2018 .

Table 5. Liquidity Ratios of Big Four Commercial Banks

\begin{tabular}{|l|r|r|r|r|r|}
\hline \multicolumn{7}{|c|}{ Years } \\
\hline Banks & 2014 & 2015 & 2016 & 2017 & 2018 \\
\hline RCB & 30.07 & 31.8 & 27.6 & 32.5 & 30.2 \\
\hline TEB & 40.99 & 38.36 & 40.18 & 44.75 & 43.57 \\
\hline NLB & 45.3 & 43.2 & 47 & 49.8 & 48 \\
\hline
\end{tabular}

Source: Authors' calculations.

Since 2014, the average liquidity ratio remained at the levels of more than $40 \%$ of these four commercial banks. It is higher than $25 \%$ of the regulatory standards. The ratio reaches to 45.95 in 2017, and it is almost twice as many as regulatory standards. In the four commercial banks, the ratios of NLB are more than $50 \%$ from 2014 to 2017. The PCB is the lowest (30.2\% in 2018), but also higher than the requirements of CBK. This information fully shows that the commercial banks holdings of liquid assets ratio are too high and it is the embodiment of the excess liquidity.

Excess liquidity of commercial banks means the excess capital. It illustrates that banks cannot find the right channel to utilize capital and money was not effective on the market. In addition, excess liquidity may trigger the exposure of other risks such as credit risk and increase the difficulty of risk management of commercial banks.

\section{Loan-to-deposit Ratio:}

Loan-to-deposit ratio is a basic indicator that measures liquidity risk of banks. It comprehensively reflects the liquidity characteristics of assets and liabilities of 
commercial banks. The liquidity is worse if the ratio is high. A lower loan-to deposit ratio means that the banks could use the stability of the deposit for the new loan financing. And the liquidity risk is relatively small. The CBK regulations the loanto-deposit ratio should not exceed $75 \%$

According to Table 6, from 2014 to 2018, the loan-to-deposit ratios of four commercial banks are below $75 \%$. In spite of this, the ratio is also on the rise year by year. With this trend, if the banks do not carry on deposit and loan management, the average loan-to-deposit ratios of commercial banks will be increased to more than $75 \%$ in the next few years. The best evidence is that the ratio of BOC has already reached $76.58 \%$ in 2018 .

Moreover, the difference between deposits and loans is also increased with years. In 2018 , the average of poor lending reached to 3,621,818 million. Investigate it reason, on the one hand, the external supervision of risk management is norms and strict increasingly. In this case, the banks must control their risk assets, namely the size of the loan. On the other hand, the main source of bank debt (deposits) has maintained growth. These two roles led to a wider difference between deposits and loans.

Table 6. The Condition of Loan-to-deposit of Big Four Commercial Banks

\begin{tabular}{|c|c|c|c|c|c|c|}
\hline Years & & $(\mathrm{RN}$ & Gillion) & & & \\
\hline Banks & & 2014 & 2015 & 2016 & 2017 & 2018 \\
\hline & $\begin{array}{l}\text { Loans and } \\
\text { advances to } \\
\text { customers }\end{array}$ & $5,318,554$ & $6,337,266$ & $7,329,882$ & $8,386,531$ & $9,457,500$ \\
\hline PCB & $\begin{array}{l}\text { Deposits from } \\
\text { customers }\end{array}$ & $9,103,898$ & $10,385,487$ & $11,364,657$ & $12,509,843$ & $13,843,197$ \\
\hline & $\begin{array}{l}\text { Loan-to- } \\
\text { deposit ratio }\end{array}$ & $58.42 \%$ & $61.02 \%$ & $64.50 \%$ & $67.04 \%$ & $68.32 \%$ \\
\hline & $\begin{array}{l}\text { Loans and } \\
\text { advances to } \\
\text { customers }\end{array}$ & $3,727,928$ & $4,616,931$ & $5,334,557$ & $6,065,274$ & $6,910,717$ \\
\hline RBKO & $\begin{array}{l}\text { Deposits from } \\
\text { customers }\end{array}$ & $6,952,751$ & $8,199,478$ & $9,187,454$ & $10,162,433$ & $11,170,828$ \\
\hline & $\begin{array}{l}\text { Loan-to- } \\
\text { deposit ratio }\end{array}$ & $53.62 \%$ & $56.31 \%$ & $58.06 \%$ & $59.68 \%$ & $61.86 \%$ \\
\hline & $\begin{array}{l}\text { Loans and } \\
\text { advances to } \\
\text { customers }\end{array}$ & $4,208,830$ & $5,396,751$ & $6,096,396$ & $6,707,626$ & $7,372,111$ \\
\hline TEB & $\begin{array}{l}\text { Deposits from } \\
\text { customers }\end{array}$ & $6,118,777$ & $7,223,062$ & $8,180,446$ & $9,095,330$ & $9,627,269$ \\
\hline & $\begin{array}{l}\text { Loan-to- } \\
\text { deposit ratio }\end{array}$ & $68.79 \%$ & $74.72 \%$ & $74.52 \%$ & $73.75 \%$ & 76.58 \\
\hline NLB & $\begin{array}{l}\text { Loans and } \\
\text { advances to } \\
\text { customers }\end{array}$ & $4,466,885$ & $5,268,333$ & $6,108,983$ & $7,027,047$ & $8,104,173$ \\
\hline & $\begin{array}{l}\text { Deposits from } \\
\text { customers }\end{array}$ & $7,365,802$ & $8,482,558$ & $9,442,374$ & $10,527,661$ & $11,690,720$ \\
\hline
\end{tabular}




\begin{tabular}{|c|c|c|c|c|c|}
\hline $\begin{array}{l}\text { Loan-to- } \\
\text { deposit ratio }\end{array}$ & $60.64 \%$ & $62.11 \%$ & $64.70 \%$ & $66.75 \%$ & $69.32 \%$ \\
\hline $\begin{array}{l}\text { AVG Balance of L and } \\
\text { A to customers }\end{array}$ & $4,430,549$ & $5,404,820$ & $6,217,455$ & $7,046,620$ & $7,961,125$ \\
\hline $\begin{array}{l}\text { AVG Balance of } \\
\text { Deposit from }\end{array}$ & $7,385,307$ & $8,572,646$ & $9,543,733$ & $10,573,817$ & $11,583,004$ \\
\hline $\begin{array}{l}\text { AVG \% of Loan-to } \\
\text { deposit ratio }\end{array}$ & $55.99 \%$ & $63.05 \%$ & $65.15 \%$ & $66.64 \%$ & $68.73 \%$ \\
\hline
\end{tabular}

Source: Authors' calculations.

With the adjustment of the banking business and the development of the off-balance sheet business, existing regulatory indexes (liquidity ratio and loan-to-deposit ratio) are hard to reflect the real banks liquidity index. As can be seen from the actual data above, in the past five years, the liquidity ratio and the loan-to-deposit ratio have been deviation obviously. Look at the liquidity ratios, it present an increasing tendency of the average liquidity of commercial banks. While the loan-to-deposit ratios show a decreasing of liquidity levels. This situation illustrates that the effectiveness of liquidity supervision is falling now. If it monitors the indicators that cannot reflect the bank liquidity position, it may form a misleading on bank liquidity risk management. And it may even aggravate the systematic liquidity risk.

\subsection{Liquidity Gap Analysis}

There is no pure static liquidity risk management, because the liquidity risk is a kind of dynamic risk from the assets movement. The static index above can be thought of as a subsequent statistics based on the current situation. To fully reflect the liquidity risk of commercial banks, it must dynamic prediction of the potential supply and demand for funds in the future for a period of time. A very important concept is "gap". Liquidity gap refers to the difference between the assets and liabilities of banks. The cause of liquidity risk of commercial banks is the mismatch of liquidity supply and demand. If the maturing assets are greater than the maturing liabilities, banks have surplus cash flow in the future and it can satisfy the need of liquidity. Table 7 summarized the situation of liquidity gap of the big four commercial banks from 2014 to 2018.

Table 7. Liquidity Gap Analysis of Big Four Commercial Banks

\begin{tabular}{|c|c|c|c|c|c|c|c|c|c|}
\hline $\begin{array}{l}\text { Ba } \\
\text { nk } \\
\text { s }\end{array}$ & Year & $\begin{array}{l}\text { Overdue/ } \\
\text { repayable } \\
\text { on } \\
\text { demand }\end{array}$ & $\begin{array}{l}\text { Less than } \\
1 \text { month }\end{array}$ & $\begin{array}{r}1 \text { to } 3 \\
\text { months }\end{array}$ & $\begin{array}{l}3 \text { months } \\
\text { to } 1 \text { year }\end{array}$ & $\begin{array}{l}1 \text { to } 5 \\
\text { years }\end{array}$ & Over 5 years & Undated & Total (M) \\
\hline \multirow{5}{*}{$\begin{array}{l}\text { PC } \\
\text { B }\end{array}$} & 2014 & $-5,844,656$ & $-64,006$ & $-66,927$ & 573,857 & $1,965,097$ & $2,457,040$ & $1,658,529$ & 678,934 \\
\hline & 2015 & $-6,585,303$ & $-162,433$ & $-301,119$ & $-383,368$ & $2,537,639$ & $3,515,949$ & $2,200,292$ & 821,657 \\
\hline & 2016 & $-6,707,099$ & $-459,158$ & $-618,315$ & $-311,001$ & $2,613,952$ & $3,815,715$ & $2,623,729$ & 957,823 \\
\hline & 2017 & $-7,008,584$ & $-439,485$ & $-461,287$ & -697 & $2,158,073$ & $4,046,904$ & $2,833,535$ & $1,128,459$ \\
\hline & 2018 & $-7,569,949$ & $-339,167$ & $-767,112$ & $-529,145$ & $2,978,075$ & $4,387,952$ & $3,117,809$ & $1,278,463$ \\
\hline \multirow{5}{*}{$\begin{array}{l}\mathbf{R} \\
\mathbf{B} \\
\mathbf{K} \\
\mathbf{O}\end{array}$} & 2014 & $-4,610,962$ & 11,497 & 187,297 & 90,335 & $1,212,325$ & $2,103,376$ & $1,229,190$ & 223,058 \\
\hline & 2015 & $-5,715,521$ & 259,754 & $-44,614$ & 280,782 & $1,465,927$ & $2,433,370$ & $1,736,220$ & 415,918 \\
\hline & 2016 & $-6,071,724$ & 101,585 & $-118,808$ & 812,393 & $1,085,901$ & $2,597,757$ & $2,115,981$ & 523,085 \\
\hline & 2017 & $-6,579,348$ & 419,330 & $-47,360$ & 717,454 & $1,053,047$ & $2,820,475$ & $2,224,021$ & 607,619 \\
\hline & 2018 & $-7,070,606$ & 355,050 & $-193,973$ & 631,324 & $1,333,003$ & $3,210,614$ & $2,405,782$ & 671,194 \\
\hline
\end{tabular}




\begin{tabular}{|l|l|l|l|l|l|l|l|l|l|}
\multirow{4}{*}{$\begin{array}{l}\text { TE } \\
\text { B }\end{array}$} & $\mathbf{2 0 1 4}$ & $-3,357,812$ & 307,603 & $-70,044$ & 132,759 & $1,744,538$ & $1,773,438$ & 14,912 & $\mathbf{5 4 5 , 3 9 4}$ \\
\cline { 2 - 10 } & $\mathbf{2 0 1 5}$ & $-3,770,963$ & 293,431 & $-107,056$ & 127,728 & $1,809,370$ & $2,312,504$ & 11,136 & $\mathbf{6 7 6 , 1 5 0}$ \\
\cline { 2 - 10 } & $\mathbf{2 0 1 6}$ & $-3,886,641$ & 625,317 & $-407,214$ & 372,733 & $1,417,396$ & $2,621,526$ & 12,777 & $\mathbf{7 5 5 , 8 9 4}$ \\
\cline { 2 - 10 } & $\mathbf{2 0 1 7}$ & $-4,302,972$ & $-701,447$ & $-224,823$ & 377,114 & $1,309,075$ & $2,684,396$ & $1,720,199$ & $\mathbf{8 6 1 , 5 4 2}$ \\
\cline { 2 - 10 } & $\mathbf{2 0 1 8}$ & $-4,563,640$ & $-552,967$ & $-140,238$ & 56,154 & $1,334,624$ & $2,937,724$ & $1,889,820$ & $\mathbf{8 6 1 , 5 4 2}$ \\
\hline \multirow{4}{*}{$\begin{array}{l}\mathbf{N} \\
\mathbf{L B}\end{array}$} & $\mathbf{2 0 1 4}$ & $-5,051,783$ & 13,717 & 51,492 & 389,074 & $1,638,064$ & $2,182,450$ & $1,336,006$ & $\mathbf{5 5 9 , 0 2 0}$ \\
\cline { 2 - 10 } & $\mathbf{2 0 1 5}$ & $-5,374,529$ & $-458,072$ & $-15,972$ & $-245,271$ & $2,041,271$ & $2,929,915$ & $1,823,563$ & $\mathbf{7 0 0 , 9 0 5}$ \\
\cline { 2 - 10 } & $\mathbf{2 0 1 6}$ & $-5,439,243$ & $-575,536$ & $-432,250$ & $-180,834$ & $2,173,385$ & $3,067,384$ & $2,203,755$ & $\mathbf{8 1 6 , 6 6 1}$ \\
\cline { 2 - 10 } & $\mathbf{2 0 1 7}$ & $-5,929,790$ & $-738,936$ & $-259,318$ & 209,588 & $1,895,777$ & $3,393,582$ & $2,378,642$ & $\mathbf{9 4 9 , 5 4 5}$ \\
\cline { 2 - 10 } & $\mathbf{2 0 1 8}$ & $-6,711,273$ & $-610,116$ & $-427,828$ & 3,773 & $2,493,591$ & $3,795,088$ & $2,531,094$ & $\mathbf{1 , 0 7 4 , 3 2 9}$ \\
\hline
\end{tabular}

Source: Authors' calculations.

As can be seen from Table 7, from 2014 to 2018, all four commercial banks show a negative gap at the first period. In spite of this, the total gaps of these banks are positive and the gap is gradually increased. The liquidity gap of PCB is the highest in the four commercial banks and it reached 1,278,463 million in 2018. This means that the financial assets of banks are bigger than the financial liabilities and showed a good liquidity. However, on the other hand, liquidity gap is the most obvious sign to prove the existence of the commercial bank liquidity risk. Nevertheless, the excessive liquidity gap shows that the excess surplus. If the gap growing, it can form liquidity traps. In this case, it will result in the outbreak of the liquidity risk.

\subsection{Interest Rate Risk}

Interest rate sensitivity gap model is an important model to measure the interest rate risk of commercial banks. It is able to judge the configuration status of assets and liabilities and the size of the risk gap, so as to help banks to determine the different assets and liabilities management strategy in different interest rates. The income structure of commercial banks in Kosovo is relatively single lead to a strong dependence on the net interest income. This dependence shows that the source of interest rate risk of banks is coming from the change of interest spreads (deposits and loans). Therefore, commercial banks in Kosovo universal use interest rate sensitive gap to measure interest rate risk since 2008. To measure the interest rate risk, the first thing to understand is the change status of Kosovo's commercial banks interest rate. Since 2008, the CBK is frequent adjustment of one-year deposit and lending rates. This situation highlights the interest rate risk of commercial banks. In 2008, under the influence of the global economic crisis, the central bank of Kosovo adjusts the deposit and lending interest rates five times and makes the interest rates are low.

\subsection{Interest Rate Sensitivity Gap Analysis}

It will not affect the non-accruals assets and liabilities if the market interest rate changes. Therefore, it only needs to consider the interest rate sensitive assets (IRSA) and the interest rate sensitive liabilities (IRSL) when analysis the interest rate risk. Interest rate sensitivity gap analysis is a management mode that making links between interest rate and duration of commercial banks assets and liabilities. Interest rate gap can be expressed as the difference between the IRSA and IRSL. As long as 
the interest rate gap is not 0 , it will be facing the interest rate risk. In addition, on the basis of the gap concept, it also could use interest rate sensitive coefficient to measure the interest rate risk of commercial banks. The coefficient is the ratio of IRSA and IRSL. Table 8 and 9 show the interest rate sensitive gap and interest rate sensitive ratios of the big four commercial banks in Kosovo, respectively.

It can be seen from Table 8, the interest rate gap of four commercial banks in 3 months are all negative from 2014 to 2018. In this case, there is a risk of liability sensitive gap. While the interest rate gap at the second period ( 3 months to 1 year) and last period (over 5 years) are all positive and this is a risk of assets sensitive gap (except NLB in 2017). In general, bigger absolute value of gap will lead to the greater interest rate risk that banks faced. As a result, commercial banks should be appropriate to reduce assets for positive interest rate gaps and decrease assets for negative interest rate gaps, in order to avoid risks brought by the changes in the interest rate.

At the same time, in addition to a few years of PCB and TEB, the accumulated interest rate sensitivity gaps of four commercial banks under five years are all negative. This means that there is a large negative sensitivity gap in the integral structure of assets and liabilities. If the central bank raised interest rates this year, the four commercial banks will face a greater interest rate risk.

Table 8. Interest Rate Sensitive Gaps of Big Four Commercial Banks

\begin{tabular}{|l|l|l|l|l|l|}
\hline & Years & Less than 3 months & 3 months to 1 years & 1 year to 5 years & $\begin{array}{l}\text { Over } \\
\text { years }\end{array}$ \\
\hline \multirow{4}{*}{ PCB } & 2014 & $-3,396,134$ & $3,299,812$ & 209,625 & 514,569 \\
\cline { 2 - 6 } & 2015 & $-4,004,468$ & $3,171,738$ & 513,833 & $1,091,312$ \\
\cline { 2 - 6 } & 2016 & $-1,887,041$ & 976,190 & 584,145 & $1,189,959$ \\
\cline { 2 - 6 } & 2017 & $-1,539,586$ & $1,340,067$ & $-48,908$ & $1,174,195$ \\
\cline { 2 - 6 } & 2018 & $-1,106,776$ & 755,071 & 473,593 & $1,091,981$ \\
\hline \multirow{5}{*}{ RBKO } & 2014 & $-1,318,506$ & 312,712 & 266,780 & $1,018,593$ \\
\cline { 2 - 6 } & 2015 & $-1,687,760$ & 91,374 & 147,712 & $1,052,323$ \\
\cline { 2 - 6 } & 2016 & $-1,555,852$ & $1,296,026$ & $-192,349$ & 997,038 \\
\cline { 2 - 6 } & 2017 & $-1,562,737$ & $1,449,840$ & $-204,422$ & 993,987 \\
\cline { 2 - 6 } & 2018 & $-1,743,645$ & $1,459,564$ & $-143,786$ & $1,200,426$ \\
\hline \multirow{5}{*}{ TEB } & 2014 & $-1,624,666$ & $1,620,260$ & 247,515 & 193,733 \\
\cline { 2 - 6 } & 2015 & $-2,062,193$ & $1,929,596$ & 271,664 & 416,987 \\
\cline { 2 - 6 } & 2016 & $-1,686,439$ & $1,703,906$ & 73,372 & 485,081 \\
\cline { 2 - 6 } & 2017 & $-1,716,129$ & $1,967,473$ & $-201,333$ & 558,406 \\
\cline { 2 - 6 } & 2018 & $-1,583,393$ & $1,901,124$ & $-382,621$ & 593,609 \\
\hline \multirow{5}{*}{ NLB } & 2014 & $-2,037,268$ & $1,786,844$ & 96,330 & 642,999 \\
\cline { 2 - 6 } & 2015 & $-1,981,441$ & $1,381,678$ & 497,390 & 713,684 \\
\cline { 2 - 6 } & 2016 & $-1,770,699$ & $1,172,398$ & 364,416 & 856,510 \\
\cline { 2 - 6 } & 2017 & $-1,755,646$ & $-1,736,008$ & $-90,498$ & 902,631 \\
\cline { 2 - 6 } & 2018 & $-1,963,877$ & $1,761,438$ & 241,112 & 902,631 \\
\hline
\end{tabular}

Source: Authors' calculations. 
Table 9. Interest Rate Sensitive Ratios of Big Four Commercial Banks

\begin{tabular}{|l|l|l|l|l|l|}
\hline & Years & $\mathbf{2 0 1 6}$ & $\mathbf{2 0 1 7}$ & $\mathbf{2 0 1 8}$ \\
\hline Banks & $\mathbf{2 0 1 4}$ & $\mathbf{2 0 1 5}$ & $\mathbf{2 0 1 6}$ & 1.072 \\
\hline PCB & 1.061 & 1.065 & 1.066 & 1.069 & 1.049 \\
\hline RBKO & 1.026 & 1.043 & 1.048 & 1.049 & 1.074 \\
\hline TEB & 1.066 & 1.069 & 1.068 & 1.073 & 1.075 \\
\hline NLB & 1.062 & 1.069 & 1.071 & 1.073 & \\
\hline
\end{tabular}

Source: Author's calculations.

Interest rate sensitivity coefficient of commercial banks in Kosovo is also growing (Table 9). The ratios are greater than 1 and commercial banks show the assets sensitive. Conservative interest rate risk management strategy is to keep the interest rate sensitive ratio around 1 . At the same time, due to market expectations that interest rates would risk, positive interest rate risk management strategy will make the assets and liabilities of banks to maintain the assets sensitivity gap. This approach not only prevents the interest rate risk, it also can get extra profits. However, the central bank reduces the benchmark interest rate in 2017, and the interest rate sensitivity ratio is still on the rise of these commercial banks. In this case, the commercial banks will reduce net interest income and it will face serious interest rate risk.

To sum up, whether the performance indicators showed positive changes or negative changes, the changes are relatively small. It reflects the continuity and stability in the development of banking and there are no drastic fluctuations. Overall, the commercial banks in Kosovo are still in a benign development stage which has relatively high profit and low risk, although the development has slowed. According to the data analysis above, the development of high profit and low risk situation may be unable to continue in the next few years.

\section{Discussion}

Kosovo is a new state and its economy has started to evolve since the 2000s, the management of commercial banks in Kosovo started late, but it still achieved some results. Risk management in the banking industry is gradually becoming systematized and institutionalized and it is an important part of enterprise management. In order to better analyze and evaluate risk, the banking risk management method is more accurate. On the basis of qualitative analysis of banking risks, it began to pay close attention to risk measurement from a quantitative perspective, such as loan risk management and five-tier NPLs. In risk management, in addition to the behavior of banks themselves, the central bank will provide a series of emergency measures for troubled banks according to the difference in risk level of commercial banks. On the other hand, the central bank also uses various measures to strengthen the supervision of commercial bank risks. It mainly regulates commercial banks operating process and standardizes their operation by some standard indexes (capital adequacy ratio, NPL ratio and ratio to NPLs, etc.). 
There are many factors that influence the risk management of commercial banks. However, the behavior of banks is the main factor that determines the size of a bank's risk. In recent years, although the legalization and institutionalization of commercial banks in risk management has made some achievements, there are also many problems that cannot be ignored. Specifically, at present, there are few effective approaches to risk identification and monitoring for the commercial banks of Kosovo. For credit risk, commercial banks mainly rely on simple quantitative analysis (the calculation of NPLs and credit risk exposure) to estimate the credit risk.

The market risk is still quantified in the initial way. Because of cost and technology, some risk management parameters and advanced risk model cannot be widely accepted and used by commercial banks in Kosovo. And for operational risk, some advanced commercial banks in the world by establishing statistical model and regression analysis that can assess the operational risk of banks. In Kosovo, the central bank released the ordinance about operating risk management in 2008, but there is no specific measurement method and scale. Therefore, the operational risk quantification is almost blank for commercial banks in Kosovo. In addition to the perfect risk system and effective risk analysis tools, risk management personnel are an important component of the commercial bank risk management. Because of Kosovo's commercial banks risk management started late, the risk management personnel cannot meet the needs of the risk management of banks. Due to the mistakes of risk management personnel, it may lead to the increase of the risk. There are three aspects to show it. Firstly, because of the credit risk is the most prominent financial risk in commercial banks of Kosovo, risk managers only pay attention to credit risk and ignore the market risk and operational risk. It shows that the risk management personnel are lack of system risk management. Secondly, in the process of risk management, risk managers also ignore the risk difference between different business and different areas. Such an act would not be able to better risk management. And it is easier to generate new risks. Finally, parts of risk management personnel simply think that little development business could control risk. It could reduce the bank risk management ability through the negative business and evade the risks.

It can be seen from the discussion above, although the credit risk, market risk and operational risk that Kosovo's commercial banks faced are the same as the other countries' banks, commercial banks in Kosovo are facing a particularity of risks due to the economic development level and policy, etc. In this situation, risk management of commercial banks in Kosovo is needed to meet this particularity. But the reality is that the risk management in Kosovo is not able to meet this requirement at present.

\section{Conclusion and Recommendations}

This research basically completes its research objective. Through the analysis of the risk situation of Kosovo commercial banks, it provides a better understanding of risk 
management for commercial banks in Kosovo. Using the quantitative analysis, this research discusses the current development of risk management of Kosovo's commercial banks, and find out the defects in the process of risk management. Although the risk management of Kosovo's commercial banks has made some achievement, there are still some insufficient. For example, the commercial banks of Kosovo do not have a complete risk management system and risk measurement. Finally, aiming at these problems, it puts forward the effective suggestions of risk management for Kosovo's commercial banks by absorbing the experience from the west commercial banks.

Risk management is a constant process of evolution. In general, risks include credit risk, market risk (include liquidity risk, interest rate risk and exchange rate risk) and operational risk. If banks ignore the risks, it could not have a normal operation. Therefore, every organisation should learn to apply effective methods and make these methods positively identification, analysis, evaluation, treatment and control business risks. The economy ofKosovo is in transition period, the development of financial market is not perfect. Under the influence, the market operation of the commercial banks will still be affected by the non-market factors. Compared with other international commercial banks, the risks of the commercial banks of Kosovo may be more uncertainty. This also means that the risk management of commercial banks in Kosovo is more challenging.

\section{References:}

Bace, E. 2016. Bank profitability: Liquidity, capital and asset quality. Journal of Risk Management in Financial Institutions.

Fan, L. \& Shaffer, S. 2004. Efficiency versus risk in large domestic US banks. Managerial Finance, 30(9), 1-19, https://doi.org/10.1108/03074350410769245

Hahm, J.H. 2004. Interest rate and exchange rate exposures of banking institutions in precrisis Korea. Applied Economics, https://doi.org/10.1080/0003684042000206979

Hassan Al-Tamimi, H.A. \& Mohammed Al-Mazrooei, F. 2007. Banks' risk management: a comparison study of UAE national and foreign banks. The Journal of Risk Finance, 8(4), 394-409, https://doi.org/10.1108/15265940710777333.

Khambata, D. \& Bagdi, R.R. 2003. Off-balance-sheet credit risk of the top 20 Japanese banks. Journal of Banking Regulation, https://doi.org/10.1057/palgrave.jbr.2340157

Niinimäki, J.P. 2004. The Effects of Competition on Banks' Risk Taking. Journal of Economics/ Zeitschrift Fur Nationalokonomie, 81(3), 199-222, https://doi.org/10.1007/s00712-003-0027-9

Oldfield, G.S. \& Santomero, A. 1997. Risk Management in Financial Institutions. Sloan Management and Review, 39(1), 33-46. Retrieved from http://papers.ssrn.com/abstract=2677051\%5Cnhttp://papers.ssrn.com/sol3/Papers.cf m?abstract_id=2677051

Sekaran, U. \& Bougie, R. 2013. Research methods for business. In Research methods for business, p. 436, https://doi.org/10.1017/CBO9781107415324.004. 